\title{
EMPOWERMENT OF ELEMENTARY SCHOOL TEACHER IN BORDER AREA
}

\author{
Anrianus $^{1)}$, M.Chiar ${ }^{2)}$, Sukmawati $^{3)}$ \\ 1), 2),3 Universitas Tanjungpura, Pontianak, Indonesia \\ E-mail: anripuspfika@gmail.com
}

\begin{abstract}
Empowerment of teachers is one form of effort that can be done to improve the process of education in schools. This study aims to find out how the process of teacher empowerment at Sontas 03 State Elementary School (SD Negeri 03 Sontas) Entikong Subdistrict, Sanggau Regency which formulated in several questions related to planning, implementation, supervision, and effectiveness of teacher empowerment at Sontas 03 State Elementary School in Entikong sub-district. The approach used in this research is qualitative descriptive with case study research type. Data collection using interview techniques, documentation and documentation. Data analysis using Miles and Huberman analysis model consist of four stages that are data reduction, data presentation, conclusion or verification. Checking or testing the validity of data is done by triangulation, member check, and increasing persistence. Summaries conducted to analyze the research findings such as: 1) Sontas 03 State Elementary School in Entikong sub-district has implemented a program of planning activities empowerment of teachers as well; 2) Teacher empowerment activities at Sontas 03 State Elementary School in Entikong sub-district have been implemented well; 3) Supervision of teacher empowerment at Sontas 03 State Elementary School in Entikong sub-district has been well implemented by supervisor and principal; 4) Empowerment of teachers at Sontas 03 State Elementary School in Entikong sub-district has been effective, the main activity of teacher empowerment is absolute.
\end{abstract}

Keywords: Teacher Empowerment; Self-Reliance; Self Confidence; Responsibility

\section{INTRODUCTION}

A leader or manager can not work alone to achieve the goals of the organization he leads. It takes a good managerial ability from a leader in moving subordinates or members in order to help him to achieve organizational goals. This is in line with the opinion expressed by Malayu Hasibuan (2016: 43) which explains "Manager is a person who achieves his goals through the activities of others".

In relation to that opinion, a leader or manager needs to be made aware of the importance of giving greater authority and trust to his subordinates (empowering members). Empowerment is an effort made to maximize or increase the potential owned by individual in an organization to become more independent. Bennis and Mische (1995: 45) explain that empowerment is "making it possible for people to use as effectively as possible their skills, experience, energy, and ambitions while at the same time demanding that they accept a wider share of responsibility and ownership of the whole process". This definition emphasizes the efforts made to maximize the potential of an individual in achieving organizational goals. Opinions that are not much different are put forward by Widodo (2015: 200) which describes empowerment as "an attempt or process to reduce dependence on subordinates to his superiors and give emphasis to the control of the individual on the responsibility for the work he does". From these two expert opinions, we can understand some basic points as follows: (1) Empowerment is an effort that emphasizes the process of giving some authority or ability (power) to individuals or groups to become more empowered. (2) Empowerment is done to maximize the potential possessed by individuals in an organization as effectively as possible. (3) Empowerment fosters independence and sense of responsibility to the individual. 
Empowerment of members or subordinates can be applied also to the world of education, specifically in schools. In the world of empowerment, education is focused on the Human Resources (HR) involved in the process of organizing education in schools. One of the main focuses of human resource empowerment in schools is teachers or better known as empowerment of teachers.

Empowerment of teachers themselves is not a strange term in the world of education. Involving teachers in the overall process of education in schools is one form of application of teacher empowerment. Teachers have a strategic role in the successful implementation of education in schools. The main task of a teacher is to educate the students through teaching and learning activities in the classroom that is the responsibility. In more detail the task of the teacher is contained in Law No. 14 of 2005 on Teachers and Lecturers explaining that "teachers are professional educators with the main task of educating, teaching guiding, directing, training, assessing, and evaluating learners on early childhood education pathways formal education, primary and secondary education ". In addition, teachers also carry out tasks outside of teaching and learning activities such as assisting students in extracurricular activities or accepting delegations of tasks or authority from the principal to perform certain tasks.

Teacher empowerment is one of the efforts that can be done by schools to maximize the potential or increase capacity owned by teachers by increasing their involvement and responsibility in the process of education in school.

The purpose of teacher empowerment is to establish teacher independence that can be seen from teachers' initiative and response in solving problems related to learning process and teaching class, or in other words, the teacher does not always depend on the principal.

Through the empowerment of teachers is expected that teachers can increasingly have sufficient knowledge and skills in accordance with their field of duty so that teachers can have confidence in carrying out the task or authority given by the principal with full responsibility.

Although it is a simple concept, in practice in the field it turns out that the empowerment of teachers is not an easy thing to do in school. To be successfully implemented requires the desire, awareness, and understanding of school principals and educational stakeholders about the importance of teacher empowerment in schools. The principal has the greatest role in the successful implementation of teacher empowerment in schools.

In this research is taken the case of implementation of teacher empowerment in school. The school in question is Sontas 03 State Elementary School located in Entikong sub-district, Sanggau District, West Kalimantan Province. Entikong Sub- district is categorized as 3T area (Front, Outermost, Remote). These sub-districts fall into the category of the foremost region or also known as the border area because the area has a direct border (land border) with the territory of the State of Sarawak, Malaysia.

Empowerment of teachers is a policy taken by UPT Education and Culture Department Entikong sub-district as one of the efforts made to overcome the problem of shortage of teachers. This policy is applied to all state elementary schools in Entikong sub-district. In the implementation stage in the field, not all schools in Entikong Sub-district are able to implement this policy maximally.

Sontas 03 State Elementary School is one of the schools that is considered successful in implementing teacher empowerment. The goal of teacher empowerment is achieved by this school, which is to produce an independent teacher, have knowledge and skill in accordance with the field of duty, confident, and responsible in carrying out the duty or authority given. One benchmark that can be used to assess the success of Sontas 03 State Elementary School in implementing teacher empowerment such as various achievements that have been achieved this school that can not be separated from the role of teachers who have done their job well.

Achievements achieved by Sontas 03 State Elementary School in the field of academic and nonacademic. In the academic field, one of the achievements achieved by Sontas 03 State Elementary School is that during the last three years this school successively became the first rank of 17 SDN in Entikong sub-district in terms of the value of the final examination of Elementary School of Primary School / MI.

In the non-academic field, one of the achievements obtained by Sontas 03 State Elementary School is to win the National Olympic Sports Olympiad (O2SN) award for three consecutive times to become the overall champion of Entikong sub-district. Although at the sub-district level did not succeed to become the overall champion, some achievements in the field of sports still successfully achieved by the students Sontas 03 State Elementary School carrying the name Entikong sub-district.

Various achievements that have been achieved by Sontas 03 State Elementary School according to the assessment of the researchers is closely related to the success of this school in implementing teacher empowerment. This success makes the school unique compared to other elementary schools in Entikong sub-district that have similar conditions and equally implement teacher empowerment in their schools.

The uniqueness is owned by Sontas 03 State Elementary School is the reason for researchers to make this school as an object of research with the aim to know how efforts have been made by this 
school so that the empowerment of teachers can be successfully implemented.

Based on the above facts, the researchers need to conduct a more in-depth study of teacher empowerment at the State Elementary School 03 Sontas Entikong sub-district, Sanggau District. The research is focused on teacher empowerment process conducted at Sontas 03 State Elementary School in Entikong sub-district with some research questions related to how planning, implementation, supervision, and effectiveness of teacher empowerment at Sontas 03 State Elementary School in Entikong sub-district.

\section{METHODOLOGY}

This research uses descriptive qualitative approach with case study research type which focused on empowerment of teacher in elementary school. Qualitative approach used by researchers because to answer research questions that have been formulated is not possible achieved by using approaches in the form of numbers or quantitative, but with a descriptive qualitative approach. The presence of researchers as a key instrument in collecting research data. The location of the research is at the Elementary School of the State 03 Sontas Entikong sub-district, Sanggau District. Sources of research data using purposive principles and snowball sampling (Sugiono, 2016: 300). Purposive is to determine the data source based on certain considerations and snowball sampling is the retrieval of data sources that initially a small amount, gradually become big until the data obtained saturated. The data collected using three techniques are in-depth interviews with some informants consisting of principals, teachers, and supervisors, equipped with observation techniques, and documentation. The data collected is then analyzed using qualitative data analysis model of Miles and Huberman (2014: 20) consisting of several stages: data reduction, data presentation, conclusion or verification. Checking or testing the validity of data is done by triangulation, member check, and increasing persistence. In general, this research consists of 3 stages, namely

\section{A. Preparation Phase}

The steps taken in the preparation phase include: (1) Communicating with the parties to be studied by way of visiting the location Sontas 03 State Elementary School in Entikong sub-district which will serve as a place of research. Communication is mainly done with the principal (2) Communicating the title of research with the lecturers I and II to get input and approval of research proposals. (3) Conducting a thesis proposal seminar and making corrections based on correction and input received from some students and lecturers.
Maintaining administrative completeness related to the implementation of research starting from the making of research permit from Faculty of Teacher Training and Education in Universitas Tanjungpura and other correspondence which is administratively related to the implementation of research. (5) Make an agreement with the principal about the timing of the research, especially agreeing on the time of interview with the principal and teacher. As much as possible the agreed time does not interfere with the teaching task of the teacher.

\section{B. Implementation Phase}

Measures were taken at the implementation stage namely: (1) Conducting research by collecting data (data collection) using in-depth interview techniques to informant research that has been determined, interview questions have been prepared previously in the form of interview guides. At the same time, researchers also make observations and documentation to complete the results of the interview. The data collected using these three techniques is done in accordance with the research grid that has been made, (2) Reduce data that has been collected (data reduction). This is done by focusing on the simplification of 'rough' data that has been collected. At this stage, the data that has been obtained is summarized and focused on the main issues related to the focus and research questions. If there is data that is not appropriate, then the data can be ignored, (3) Make the presentation of data (data display) to the research findings. The presentation of data is done in the form of narrative text that is equipped with some tables and images so that the data displayed more easily understood.

C. Final Stage

Steps taken in the final stages namely: (1) Conduct discussion and analysis of research findings. (2) Checking the validity of data using triangulation, member check, and increasing persistence. (3) Drawing conclusions based on the results of the discussion and analysis of the research findings in accordance with the formulation of problems that have been made. (4) Following the research report in the form of a complete thesis that will be tested through the feasibility trial and thesis session.

\section{RESULTS AND DISCUSSION}

\section{A. Research Results}

Based on the data obtained through interview techniques to informants, observation and documentation found some research results related to the implementation of teacher empowerment at Sontas 03 State Elementary School in Entikong subdistrict. The findings are further discussed in accordance with the research focus and question set.

1. Teacher Empowerment Planning at Sontas 03 State Elementary School in Entikong sub-district. 
Based on the results of the analysis of research findings data related to teacher empowerment planning in Sontas 03 State Elementary School in Entikong sub-district found that schools always do planning activities at the beginning of each school year involving all education stakeholders in the school that is the principal, the entire board of teachers and representatives of parents in school Committee. This planning activity is held in a meeting forum. Relevant data for planning and evaluation results on the execution of activities in the previous year is used as the basis for consideration to make the planning for the current plan is better than the previous year. It is also useful to identify the strengths, weaknesses, ease, and obstacles that will be faced by schools in carrying out the planned activities. In the meeting also discussed how the resources owned by schools in the year that includes the state of teachers and the budget that is owned for the implementation of the program activities. All participants of the meeting are given equal opportunity to express their ideas or ideas about what activities will be carried out by the school. Decisions about the best ideas or ideas are taken by deliberation of consensus by considering the school's budgetary capacity. Planning is made per activity and each activity is set a series of goals to be achieved. The final result of the planning activities undertaken is in the form of School Activity and Budget (RKAS) documents that apply for one lesson year. Teacher empowerment activities are not specifically planned in a particular activity but are implied in every program of activity contained in the RKAS document. Based on the research findings it can be seen that the planning activities implemented by Sontas 03 State Elementary School have been in accordance with the four basic stages of planning as described by Handoko (2013: 79) which explains that basically all planning activities through four stages namely; "Set goals, formulate current circumstances, identify convenience and constraints, and develop a series of activities". Engaging teachers actively in planning activities related to the development of eight educational standards is the first step taken by principals to empower teachers.

2. Implementation of teacher empowerment at Sontas 03 State Elementary School in Entikong sub-district.

Based on the results of data analysis of research on the implementation of teacher empowerment in Sontas 03 State Elementary School in Entikong sub-district found that the form of teacher empowerment conducted at Sontas 03 State Elementary School in Entikong sub-district is to increase their involvement in the whole process of education in schools starting from planning, implementation and evaluation. To increase the involvement of teachers in the whole process of education in schools, the principal performs the division of tasks accompanied by providing details of the task to all teachers so that they know what the tasks and responsibilities. This assignment is contained in a Decree (SK), and a letter of assignment to perform certain tasks assigned by the principal. In addition to providing assignments that are attached to the main task of the teacher, the principal also delegates the task to the teacher to replace him in performing certain tasks when the principal is absent. This form of delegation of authority, for example, gives teachers the confidence to become Plt. Headmaster, becomes the head of the new admissions committee, and accompanies the students when they attend activities at the district level where the principal can not follow. In the implementation of the task the principal provides motivation, direction and guidance to the teacher because it is true that the empowerment of teachers is an important thing to do because without the help and cooperation of teachers implementation of education will not succeed. Empowerment of teachers is one form of regeneration conducted by the principal to the teacher. The principal gives full confidence to the teacher to carry out his duties because the principal has the belief that the assigned teacher has the ability to execute it. If in the implementation of the task found the teacher constraints to communicate with the principal to find a way out. To discuss the findings of the research results that have been described previously researchers using Khan empowerment model (in Widodo, 2015: 203-205) consisting of six successive stages namely; Desire, Trust, Confidence, Credibility, Accountability, and Communication. The following discussion of the implementation of teacher empowerment at Sontas 03 State Elementary School using Khan empowerment model. (1) Desire (desire) desire is the desire to implement empowerment, in this context the desire is owned by the principal, (2) Trust (belief) implemented by the principal by providing delegation of duties and authority to teachers. The assignment is a form of school principal's confidence to the teacher, (3) Confident (Appearance) Appears as a result of the trust given by the principal to the teacher through. The teacher feels that the abilities and skills possessed are rewarded by the principal, (4) The credibility of the teacher maintains the trust that the principal has given to carrying out the full responsibility of the principal. (5) Accountability (accountability) teachers provide a form of responsibility for the implementation of the task given. For example by providing reports on the implementation of activities that are the responsibility to the principal. (6) Communication (communication) established two-way communication between teachers and principals. The established communication is not rigid, and done not too formal. Teacher gather time during break time can be used to communicate. Things that are 
communicated relate to the implementation of teacher duties. Based on the discussion of research findings it can be understood that the implementation of teacher empowerment in Sontas 03 State Elementary School has been in accordance with Khan empowerment model.

3. Supervision of teacher empowerment at Sontas 03

State Elementary School in Entikong sub-district.

Based on the analysis of research data on teacher empowerment control in Sontas 03 State Elementary School in Entikong sub-district found that supervision of teacher empowerment activities conducted by supervisors and principals. Because the form of implementation of teacher empowerment at Sontas 03 State Elementary School is embedded in the process of organizing education, then automatically teacher empowerment activities are part of the main task of school supervisor. this is in accordance with Permenpan RB Number 21 Year 2010 About Functional Position of School Supervisor and Credit Score which explains that the school supervisor has the main duty to supervise the implementation of education in schools that become its target area. The supervisory forms undertaken by supervisors are attached to their duties when supervising the principal to the principal and supervising the teacher. While the form of supervision conducted by the principal on the implementation of teacher empowerment is done directly on the implementation of the program activities assigned or the responsibility of the teacher. The RKAS document is used by the principal as a guide to finding out whether the activities are carried out in accordance with the plans that have been made. If in the implementation of the activity is found non-conformity with the plan that has been made, it will be done corrective action. At the end of the school year, the principal conducts an evaluation meeting to determine the extent of the success of the program activities that have been implemented, the results of this evaluation will be used as a consideration for further planning. As with planning activities, evaluation activities are also conducted in forum meetings involving all teacher board teachers. To discuss the research findings that have been described previously, researchers compared the monitoring process conducted in Sontas 03 State Elementary School in Entikong sub-district with a supervisory process that was discovered by Handoko (2013: 360-363) consisting of five stages namely; setting implementation standards, determining the measurement of implementation, measuring the implementation of activities, benchmarking with evaluation standards, and taking corrective action if necessary. In accordance with the research findings, the stages one and two have been implemented by Sontas 03 State Elementary School when formulating the RKAS document. This document is used as the standard and measure of the implementation of activities. Furthermore, phase three is done by the principal of the implementation of activities that are the responsibility of the teacher. This measurement is done by the principal in two ways, namely through direct observation and reports of activities provided by the teacher. In the fourth stage, the principal performs a comparison between the standards that have been made with the results of the measurement of the implementation of the activities. This stage is also known as the activity evaluation. In the fifth stage corrective action is taken when necessary. Corrective action can be done at each stage. This action can be taken in various forms, amongst others by changing standards, improving implementation, or doing both simultaneously. Based on the findings of research related to the supervision of teacher empowerment at Sontas 03 State Elementary School in Entikong sub-district, we can know that the supervision is done in accordance with the supervision process as has been stated by Handoko.

4. The effectiveness of teacher empowerment at Sontas 03 State Elementary School in Entikong sub-district.

Based on the analysis of research data on the effectiveness of teacher empowerment at Sontas 03 State Elementary School in Entikong sub-district found that the empowerment of teachers conducted by increasing the involvement of teachers in the entire process of education provision to grow the independence of teachers in carrying out the tasks assigned by the principal. This independence can be seen from the initiative, response, and creativity possessed by the teacher in carrying out the tasks assigned by the principal. Teachers at Sontas 03 State Elementary School do not always depend on the principal when they are given responsibility for performing certain tasks. They have the confidence that with the knowledge and skills that the assigned tasks can perform well. In addition to growing the independence of teachers, teacher empowerment activities are also increasingly increasing the insight, skills, and experience of teachers who ultimately make teachers have confidence in carrying out tasks assigned to him with full responsibility. Effectiveness is closely related to the achievement of organizational goals. Husna Asmara (2016: 138) put forward his opinion that "effectiveness in general shows how farreaching a goal is first determined". Based on the findings of research relating to the effectiveness of teacher empowerment at Sontas 03 State Elementary School in Entikong sub-district and expert opinion we can understand that the effectiveness of teacher empowerment at Sontas 03 State Elementary School in Entikong sub-district one can be measured to what extent achievement of teacher empowerment goals. The main goal of teacher empowerment is to develop self-reliance in the teacher. Thus it can be seen that the implementation of teacher empowerment in 
Sontas 03 State Elementary School can be said to successfully achieve the goals set.

\section{CONCLUSION AND SUGGESTION}

\section{A. Conclusions}

Based on the findings and discussion of research results in the previous section of the process of empowerment of teachers at Sontas 03 State Elementary School in Entikong sub-district, according to the focus and research questions that have been formulated can be summed up some of the following points:

1. Teacher empowerment planning at Sontas 03 State Elementary School in Entikong sub-district has been well implemented. Planning of teacher empowerment activities is carried out in conjunction with other program planning activities that are an integral part of the RKAS document. Planning activities involve teachers actively by providing ideas or ideas related to the program activities that will be done school, this is a form of teacher empowerment. This school has been planning according to the four basic stages of planning consisting of setting goals, formulating the present situation, identifying the ease and constraints, and developing a series of activities.

2. Teacher empowerment activities at Sontas 03 State Elementary School have been well implemented. The form of implementation of teacher empowerment in this school is to increase the involvement of teachers in the whole process of education in Sontas 03 State Elementary School. The efforts made by schools to increase the involvement of teachers is to provide duties and responsibilities to teachers to implement the program activities contained in the document RKAS. Implementation of empowerment of teachers in this school is also in accordance with the model of empowerment Khan used by researchers to assess the implementation of teacher empowerment in this school. This model consists of six stages sequentially can be described as follows: desire, confidence, confidence, credibility, accountability, and communication.

3. Supervision of teacher empowerment at Sontas 03 State Elementary School has been done well. Supervision is done by supervisors and principals. The principal has a greater responsibility for supervision because the principal is the initiator, executive, and supervisor in the implementation of teacher empowerment activities. The supervisory process is carried out through five stages: stipulating implementation standards, determining the measurement of implementation, measuring the implementation of activities, comparing with evaluation standards, and taking corrective action if necessary

4. Teacher empowerment activities at Sontas 03 State Elementary School in Entikong sub-district have been effective. The benchmark used to assess the effectiveness of teacher empowerment is the achievement of the teacher's educational activities objectives. Implementation of teacher empowerment at Sontas 03 State Elementary School enhances the independence, insight, and skills of teachers through the tasks and responsibilities afforded to them. This fosters their confidence in performing the tasks assigned to them.

B. Suggestion

Based on the results of the research and the conclusion above, it is suggested to other researchers, if you want to do a similar research or further research related to the implementation of teacher empowerment in schools should not only focus on the process of teacher empowerment implemented in schools but also on school management activities to implement teacher empowerment in schools.

\section{REFERENCES}

Asmana, Urai Husna. 2015. Kepemimpinan Teori dan Aplikasi. Pontianak: Faruna Bahagia Press.

Bennis, Warren \& Michael Mische. 1997. Organisasi Abad 21 terjemahan. Jakarta: Pustaka Binaman Pressindo

Handoko, T Hani. 2013. Manajemen Edisi 2. Yogyakarta: Fakultas Ekonomi dan Bisnis UGM.

Hasibuan, Malayu. 2016. Manajemen Dasar Pengertian dan Masalah. Jakarta: Bumi Aksara.

Miles, Matthew B dan Michael Huberman. 2014. Analisis Data Kualitatif. Jakarta: Universitas Indonesia Press.

Sugiyono (2014). Memahami Penelitian Kualitatif. Bandung. Alfabeta.

Widodo, Suparno Eko. 2015. Manajemen Pengembangan Sumber Daya Manusia. Yogyakarta: Purtaka Pelajar.

Undang-Undang Nomor 14 Tahun 2005 Tentang Guru dan Dosen.

Permenpan RB Nomor 21 Tahun 2010 Tentang Jabatan Fungsional Pengawas Sekolah dan Angka Kreditnya. 